\title{
PENGARUH SUPERVISI KEPALA MADRASAH DAN KEMAMPUAN PENGGUNAAN TEKNOLOGI TERHADAP KINERJA GURU MAN DI KOTA MEDAN
}

\author{
Lily Primamori Harahap \\ Program Studi Magister Manajemen Pendidikan Tinggi, \\ Pascasarjana Universitas Muhammadiyah Sumatera Utara Medan, Sumatera Utara, Indonesia \\ Email: www.lilymunawierhrp@gmail.com
}

\begin{abstract}
Abstrak
Kompetensi manajerial kepala madrasah dapat melakukan proses supervisi kepada guru dalam proses pembelajaran. Tetapi pada kenyataannya, masih saja ada kepala madrasah yang belum mampu melakukan tugasnya sesuai dengan kompetensi manajerialnya yaitu melakukan supervisi. Salah satu indikator seorang guru yang profesional adalah memiliki kemampuan mengelola dan menggunakan media atau sumber belajar. Sehingga seorang guru harus dapat menggunakan teknologi untuk mengikuti perkembangan zaman. Tetapi pada kenyataannya masih banyak guru terbiasa dengan metode konvensional dalam pembelajaran.

Tujuan penelitian: (1) mengetahui pengaruh supervisi kepala madrasah terhadap kinerja guru (2) mengetahui pengaruh kemampuan penggunaan teknologi terhadap kinerja guru (3) mengetahui pengaruh supervisi kepala madrasah dan kemampuan penggunaan teknologi terhadap kinerja guru. Penelitian ini bertempat di MAN 1 Medan dan MAN 2 Medan di Jalan Williem Iskandar no. 7 dan 7A Medan. Jenis penelitian: kuantitatif, jumlah populasi 244 orang dan sampel 150 orang menggunakan metode Slovin.

Hasil penelitian menunjukkan bahwa (1) Terdapat pengaruh positif dan signifikan antara supervisi kepala madrasah terhadap kinerja guru. Supervisi kepala madrasah memberikan pengaruh terhadap kinerja guru sebesar $6,1 \%$ dan sisanya yaitu 93,9\% ditentukan oleh faktor lainnya; (2) Terdapat pengaruh positif dan signifikan antara kemampuan penggunaan teknologi terhadap kinerja guru. Kemampuan penggunaan teknologi memberikan pengaruh terhadap kinerja guru sebesar 10,3\% dan sisanya yaitu 89,7\% ditentukan oleh faktor lainnya; (3) Terdapat pengaruh positif dan signifikan antara supervisi kepala madrasah dan kemampuan penggunaan teknologi secara bersama-sama terhadap kinerja guru. Supervisi kepala sekolah dan kemampuan penggunaan teknologi secara bersama-sama memberikan pengaruh terhadap kinerja guru sebesar $16,5 \%$ dan sisanya yaitu 83,5\% ditentukan oleh faktor lainnya.
\end{abstract}

Kata Kunci : Supervisi, Kemampuan Penggunaan Teknologi, Kinerja

\section{PENDAHULUAN}

Menurut permendiknas Nomor 20 Tahun 2003 bahwa kompetensi manajerial seorang kepala madrasah haruslah dapat melakukan proses supervisi baik kepada guru atau pegawai yang memiliki kaitan langsung dengan proses pembelajaran di madrasah. Dan dalam Permendiknas Nomor 41 Tahun 2007 Tentang Standar Proses pada bagian V mengenai Pengawasan Proses Pembelajaran poin B dengan penjelasan: (1) Supervisi proses pembelajaran dilakukan pada tahap perencanaan, pelaksanaan, dan penilaian hasil pembelajaran; (2) Supervisi pembelajaran dilakukan dengan cara pemberian contoh, diskusi, pelatihan, dan konsultasi; (3) Kegiatan supervisi dilakukan oleh kepala dan pengawas satuan pendidikan. Dari sini jelas tidak ada satupun proses penyelenggaraan pendidikan yang terlepas dari kegiatan supervisi pendidikan.

Tetapi pada kenyataannya, masih saja ada kepala madrasah yang belum mampu melakukan tugasnya sesuai dengan kompetensi manajerialnya yaitu melakukan supervisi di madrasah yang dipimpinnya. Di lain kasus, kepala madrasah sudah melakukan supervisi terhadap guru tetapi belum mampu melaksanakannya secara optimal. Untuk meningkatkan kinerja guru, supervisi tidak bisa hanya berhenti pada tahap pelaksanaan saja tetapi harus ada tindak lanjut terhadap hasil supervisi yang telah dilakukan dan diharapkan akan meningkatkan kinerja guru. Akan tetapi kenyataannya dengan kegiatan supervisi yang telah dilakukan, masih ada juga guru yang belum menampakkan peningkatan kinerja secara signifikan.

Indikator kompetensi profesional guru dalam proses belajar mengajar menurut Permendiknas Nomor 16 Tahun 2007 salah satunya adalah kemampuan mengelola program belajar mengajar dengan menggunakan pemanfaatan teknologi informasi. Tetapi hal ini banyak menuai hambatan, karena kemajuan teknologi tidak selalu diikuti dengan kualitas sumber daya manusia. Untuk menyelaraskan kemajuan teknologi dan kualitas guru masih sulit dilakukan karena kebanyakan guru masih terbiasa dengan metode konvensional dalam proses pembelajaran, yaitu metode ceramah yang berorentasi pada konten untuk menyelesaikan materi, padahal madrasah telah memiliki sarana dan prasarana pendukung pembelajaran berbasis teknologi informasi seperti laboratorium komputer, $L C D$ projector dan akses internet.

Di MAN kota Medan, fasilitas yang mendukung pemanfaatan teknologi telah tersedia. Contohnya di MAN 2 Model Medan, disetiap kelas telah terpasang proyektor, pengeras suara (loudspeaker) dan wifi sehingga memudahkan guru untuk menyampaikan materi secara audio, visual maupun 
audiovisual. Tetapi dengan tersedianya teknologi yang mendukung pembelajaran di setiap kelas ini, masih saja ada guru yang dalam mengajar tidak menggunakan teknologi tersebut.

Menurut Chaidar Husain terdapat lima masalah yang menjadi penghambat dalam pemanfaatan teknologi informasi dalam dunia pendidikan yaitu sebagai berikut: (1) Masalah teknis, misalnya tidak stabilnya jaringan internet; (2) media pengajaran guru dituntut harus lebih kreatif dan matang; (3) Keterbatasan tenaga operasional; (4) Kurangnya kompetensi guru dalam memanfaatkan teknologi informasi; (5) Masalah pembiayaan.

Guru merupakan kunci keberhasilan mutu pendidikan. Sebagai tenaga profesional, guru juga memerlukan pengawasan serta bimbingan demi memperbaiki pelaksanaan proses belajar mengajar yang telah mereka lakukan selama ini. Salah satunya adalah pengawasan yang dilakukan oleh kepala madrasah. Berdasarkan prinsip pembelajaran pada kurikulum 2013, guru dituntut mengubah mindset dan kebiasaan lama mengajar di depan kelas dengan menerapkan salah satu prinsip pembelajaran pada kurikulum 2013 yaitu penggunaan teknologi informasi secara terintegrasi yang dapat mengarahkan peserta didik berpikir kritis dan analitis.

\section{KAJIAN PUSTAKA}

\section{Kajian Teoritik}

a. Supervisi

Menurut Mulyasa (2012;28) supervisi secara etimologi berasal dari kata "super" dan "visi" yang mengandung arti melihat dan meninjau dari atas atau menilik dan menilai dari atas yang dilakukan oleh pihak atasan terhadap aktivitas, kreativitas, dan kinerja bawahan.

Sahertian $(2000 ; 21)$ supervisi adalah usaha memberikan pelayanan dan bantuan kepada guru-guru baik secara individual maupun secara kelompok dalam usaha memperbaiki pengajaran.

Fungsi supervisi menurut Pidarta (2009;3) adalah membantu sekolah menciptakan lulusan yang baik dalam kuantitas dan kualitas, serta membantu para guru agar bisa dan dapat bekerja secara profesional sesuai dengan kondisi masyarakat tempat sekolah itu berada.

b. Kepala Madrasah

Menurut Peraturan Menteri Pendidikan Nasional No. 28 tahun 2010 tentang Penugasan Guru Sebagai Kepala Sekolah/Madrasah, "Kepala sekolah/ madrasah adalah guru yang diberi tugas tambahan untuk memimpin taman kanak- kanak/raudhotul athfal (TK/RA), taman kanak-kanak luar biasa (TKLB), sekolah dasar/madrasah ibtidayah (SD/MI), sekolah dasar luar biasa (SDLB), sekolah menengah pertama/madrasah tsanawiyah (SMP/MTs), sekolah menengah pertama luar biasa
(SMPLB), sekolah menengah atas/madrasah aliyah (SMA/MA), sekolah menengah kejuruan/madrasah aliyah kejuruan (SMK/MAK), atau sekolah menengah atas luar biasa (SMALB) yang bukan sekolah bertaraf internasional (SBI) atau yang tidak dikembangkan menjadi sekolah bertaraf internasional (SBI).”

Menurut Munir (2008), kepemimpinan kepala madrasah adalah cara atau usaha kepala madrasah dalam mempengaruhi, mendorong, membimbing, mengarahkan dan menggerakkan guru, staf, peserta didik, orang tua peserta didik dan pihak terkait untuk bekerja atau berperan guna mencapai tujuan yang ditetapkan.

Permendiknas Nomor 13 Tahun 2007 tentang Standar Kepala Sekolah/Madrasah yang salah satunya memiliki fungsi supervisi yang kompetensinya adalah sebagai berikut:

- Merencanakan program supervisi akademik dalam rangka peningkatan profesionalisme guru.

- Melaksanakan supervisi akademik terhadap guru dengan menggunakan pendekatan dan teknik supervisi yang tepat.

- Menindaklanjuti hasil supervisi akademik terhadap guru dalam rangka peningkatan profesionalisme guru.

c. Penggunaan Teknologi Informasi dalam Dunia Pendidikan

Undang-undang ITE Nomor 19 pasal 1 ayat 3 tahun 2016 mengemukakan bahwa teknologi informasi adalah suatu teknik untuk mengumpulkan, menyiapkan, menyimpan, memproses, mengumumkan, menganalisis, dan atau menyebarkan informasi.

d. Kinerja Guru

Menurut Permendiknas Nomor 16 Tahun 2007 Standar kompetensi guru dikembangkan secara utuh dari empat kompetensi utama, yaitu kompetensi pedagogik, kompetensi kepribadian, kompetensi sosial, dan kompetensi profesional. Keempat kompetensi tersebut terintegrasi dalam kinerja guru. Pengukuran kinerja tersebut meliputi perencanaan, pelaksanaan, dan penilaian. Perencanaan mencakup administrasi yang harus dipersiapkan sebelum melaksanakan kegiatan pembelajaran, seperti RPP, Silabus, Program Semester, Program Tahunan Kegiatan yang dilaksanaan sejak proses pembelajaran dimulai hingga selesai.

Menurut Mulyasa, (2004;136) kata kinerja dalam bahasa Indonesia adalah terjemah dari kata dalam bahasa Inggris Performance yang berarti pekerjaan, perbuatan, penampilan, dan pertunjukan. kinerja dapat diartikan sebagai prestasi kerja, pelaksanaan kerja, pencapaian kerja, atau unjuk kerja. 
Penilaian kinerja adalah penilaian yang dilakukan terhadap setiap butir kegiatan tugas utama guru dalam rangka pembinaan karir, kepangkatan dan jabatannya. Adapun fungsinya menurut Peraturan Menteri Negara Pendayagunaan Aparatur Negara dan Reformasi Birokrasi Nomor16 Tahun 2009 sebagai berikut:

- Menilai unjuk kerja (kinerja) guru dalam menerapkan semua kompetensi yang diwujudkan dalam pelaksanaan tugas utamanya pada proses pembelajaran, pembimbingan, atau pelaksanaan tugas tambahan yang relevan dengan fungsi sekolah/madrasah. Dengan demikian, hasil penilaian kinerja menjadi profil kinerja guru yang dapat memberikan gambaran kekuatan dan kelemahan guru. Profil kinerja guru juga dapat dimaknai sebagai suatu analisis kebutuhan atau audit keterampilan untuk setiap guru yang dapat dipergunakan sebagai dasar untuk merencanakan pengembangan keprofesian berkelanjutan bagi guru.

- Menghitung angka kredit yang diperoleh guru atas kinerja pembelajaran, pembimbingan, atau pelaksanaan tugas tambahan yang relevan dengan fungsi sekolah/madrasah pada tahun penilaian kinerja guru dilaksanakan. Kegiatan penilaian kinerja dilakukan setiap tahun sebagai bagian dari proses pengembangan karir dan promosi guru untuk kenaikan pangkat dan jabatan fungsionalnya.

\section{Kerangka Konseptual}

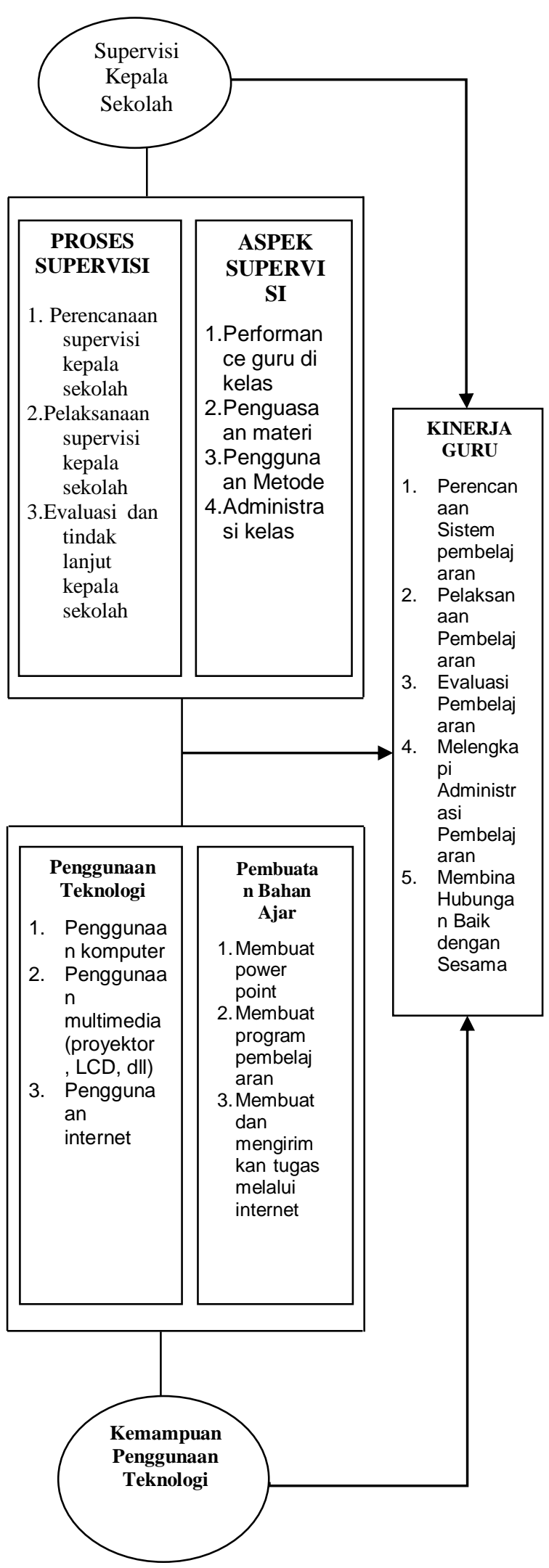

Gambar 2.1. Kerangka Konseptual 


\section{METODE PENELITIAN}

Penelitian ini dilakukan di MAN 1 Medan dan MAN 2 Medan. Metode yang digunakan dalam penelitian ini adalah metode penelitian kuantitatif. Penelitian kuantitatif yaitu penelitian yang menekankan pada data-data statistika.

Populasi dari penelitian ini adalah seluruh guru yang aktif di MAN 1 Medan dan MAN 2 Medan yang berjumlah 244 orang. Sampel penelitian adalah kepala madrasah selaku supervisor dan para guru yang aktif di madrasah tersebut yang berjumlah 150 orang dan ditentukan dengan menggunakan metode Slovin. Teknik pengumpulan data penelitian ini menggunakan angkat (Questionaries) menggunakan Skala Likert dengan interval 1 -5 dan kisi - kisi intrumen penelitian.

Uji instrumen dilakukan dua tahap. Tahapan pertama dilakuakn dengan uji Validitas dan reliabilitass dan tahapan kedua dengan melakukan uji penelitian terhadapa instrumen.

Pengujian Analisis Data harus memenuhi uji asumsi klasik terlebih dahulu. Uji asumsi klasik yang digunakan yaitu: uji normalitas, uji multikolinearitas dan uji heterokedastisitas.

Uji analisis yang digunakan adalah Regresi berganda, Uji Parsial (Uji-t) dan Uji Simultan (Uji-F). Uji Regresi untuk menguji apakah ada hubungan antara variabel bebas dengan variabel terikat. Uji simultan (ujiF) untuk mengetahui seberapa besar pengaruh semua variabel bebas (XI dan X2) secara bersama-sama terhadap variabel terikat (Y). Dan uji parsial (uji-t) untuk mengetahui seberapa besar pengaruh setiap variabel bebas secara sendiri-sendiri $(\mathrm{X} 1, \mathrm{X} 2)$ terhadap variabel terikat (Y).

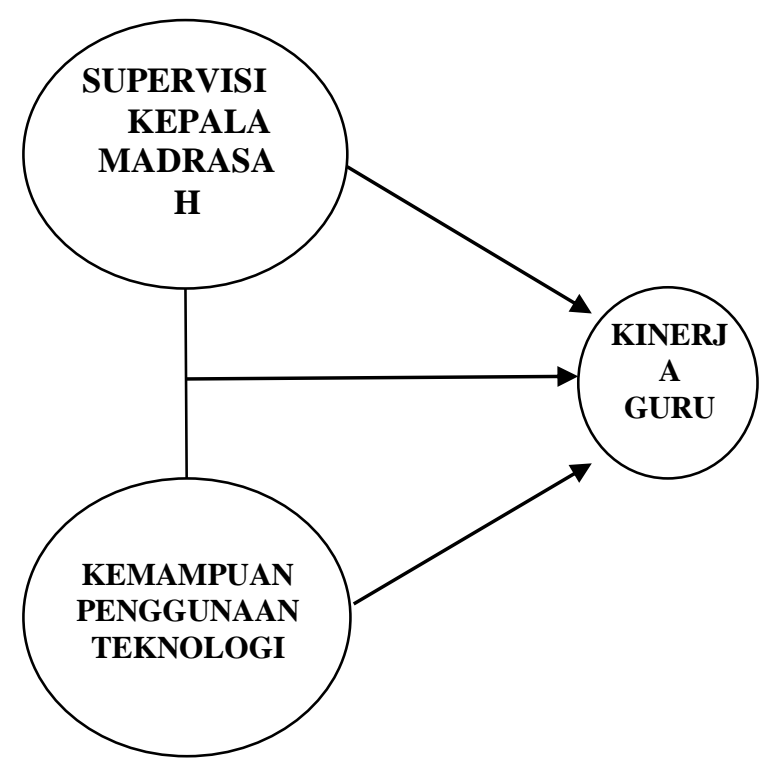

\section{Gambar 3.1 rancangan penelitian}

\section{HASIL DAN PEMBAHASAN}

Untuk menguji kelayakan model regresi yang digunakan maka harus terlebih dahulu memenuhi uji asumsi klasik. Uji asumsi klasik yang digunakan dalam penelitian ini adalah uji normalitas, uji multikolinearitas dan uji heterokedastisitas.

\section{a. Uji Normalitas}

\begin{tabular}{|c|c|c|c|c|c|c|}
\hline \multicolumn{7}{|c|}{$\begin{array}{c}\text { Normalitas Kolmogorov-Smirnov } \\
\text { Tests of Normality }\end{array}$} \\
\hline & \multicolumn{3}{|c|}{$\begin{array}{l}\text { Kolmogorov- } \\
\text { Smirnov }^{\mathrm{a}}\end{array}$} & \multicolumn{3}{|c|}{ Shapiro-Wilk } \\
\hline & $\begin{array}{l}\text { Statist } \\
\text { ic }\end{array}$ & df & Sig. & $\begin{array}{l}\text { Statist } \\
\text { ic }\end{array}$ & df & $\begin{array}{c}\text { Sig } \\
\text {. }\end{array}$ \\
\hline $\begin{array}{l}\text { Supervi } \\
\text { si }\end{array}$ & ,052 & $\begin{array}{r}15 \\
0\end{array}$ & ,200* & ,986 & $\begin{array}{r}15 \\
0\end{array}$ & $\begin{array}{r}12 \\
6\end{array}$ \\
\hline $\begin{array}{l}\text { Teknolo } \\
\text { gi }\end{array}$ & ,067 & $\begin{array}{r}15 \\
0\end{array}$ & ,095 & ,989 & $\begin{array}{r}15 \\
0\end{array}$ & $\begin{array}{r}28 \\
9\end{array}$ \\
\hline Kinerja & ,058 & $\begin{array}{r}15 \\
0 \\
\end{array}$ &, $200^{*}$ & ,985 & $\begin{array}{r}15 \\
0 \\
\end{array}$ & $\begin{array}{r}\mathbf{, 0 9} \\
1 \\
\end{array}$ \\
\hline
\end{tabular}

*. This is a lower bound of the true significance.

a. Lilliefors Significance Correction

Sumber: Pengolahan Data SPSS Tahun 2019

Dari data diatas dapat diketahui bahwa:

- Variabel Supervisi Kepala Madrasah (X $\left.\mathrm{X}_{1}\right)$ adalah 0,200 yang berarti 0,200>0,05, maka data berdistribusi normal.

- Variabel Kemampuan Penggunaan Teknologi $\left(\mathrm{X}_{2}\right)$ adalah 0,095 yang berarti $0,095>0,05$, maka data berdistribusi normal.

- Variabel Kinerja (Y) adalah 0,200 yang berarti $0,200>0,05$, maka data berdistribusi normal.

\section{b. Uji Multikolinearitas}

Angka Tolerance dan VIF Coefficients $^{\mathrm{a}}$

\begin{tabular}{|c|l|c|c|}
\hline \multirow{2}{*}{ Model } & \multicolumn{2}{c|}{ Collinearity Statistics } \\
\cline { 3 - 4 } & Tolerance & VIF \\
\hline \multirow{2}{*}{1} & (Constant) & & \\
\cline { 2 - 4 } & Supervisi & 1,000 & 1,000 \\
\cline { 2 - 4 } & Teknologi & 1,000 & 1,000 \\
\hline
\end{tabular}

a. Dependent Variable: Kinerja

Sumber: Pengolahan Data SPSS Tahun 2019

Dari tabel diatas dapat dilihat bahwa:

- variabel Supervisi nilai Tolerance-nya adalah 1,000 dan nilai VIF 1,000. Hal ini menunjukkan bahwa tidak terjadi multikolinearitas dalam model regresi.

- variabel kemampuan Penggunanaan Teknologi nilai Tolerance adalah 1,000 dan nilai VIF 1,000. Hal ini menunjukkan bahwa tidak terjadi multikolinearitas dalam model regresi.

Dari Uji multikolinearitas ini dapat dilihat adanya korelasi antara variabel independen (bebas) dan tidak terjadi permasalahan multikolinearitas. 


\section{c. Uji Heterokedastisitas}

Adapun cara untuk mendeteksi ada atau tidaknya heterokedastisitas, antara lain dengan melihat grafik Scatterplot dan menggunakan Uji Glejser.

Hasil uji Scatterplot:

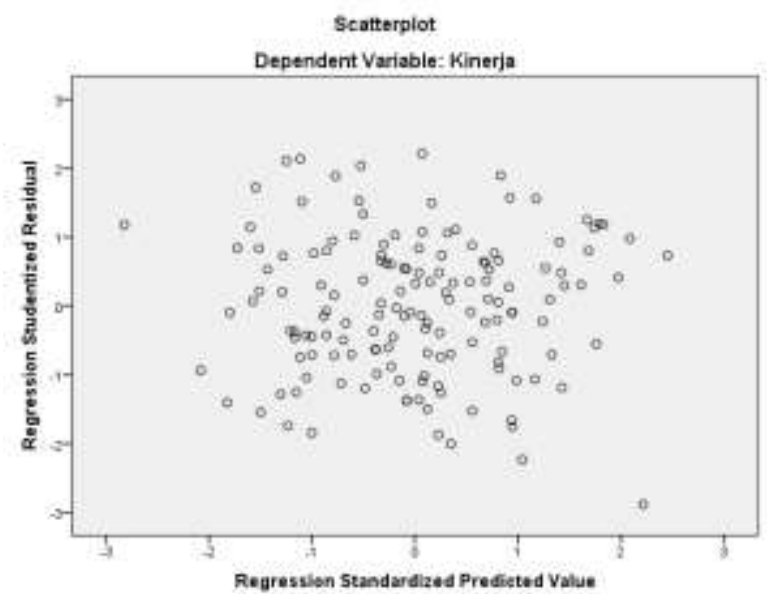

Gambar Grafik Scatterplot

Berdasarkan output Grafik Scatterplot diatas, terlihat bahwa titik-titik menyebar dan tidak membentuk pola tertentu yang jelas. Sehingga dapat disimpulkan bahwa tidak terjadi gejala heterokedastisitas.

Hasil uji Glejser: Coefficients $^{\mathbf{a}}$

\begin{tabular}{|c|c|c|c|c|c|}
\hline \multirow[t]{2}{*}{ Model } & \multicolumn{2}{|c|}{$\begin{array}{l}\text { Unstandardize } \\
\text { d Coefficients }\end{array}$} & \multirow{2}{*}{$\begin{array}{c}\begin{array}{c}\text { Standardi } \\
\text { zed } \\
\text { Coefficien } \\
\text { ts }\end{array} \\
\text { Beta }\end{array}$} & \multirow[t]{2}{*}{$\mathrm{T}$} & \multirow[t]{2}{*}{ Sig. } \\
\hline & B & $\begin{array}{l}\text { Std. } \\
\text { Error }\end{array}$ & & & \\
\hline (Constant) & $\begin{array}{r}8,93 \\
0\end{array}$ & 7,820 & & $\begin{array}{r}1,14 \\
2\end{array}$ & ,255 \\
\hline 1 Supervisi & , 015 & ,033 &,- 037 &,- 443 & ,658 \\
\hline Teknologi & ,021 & ,058 & ,030 & ,361 & ,719 \\
\hline
\end{tabular}

a. Dependent Variable: Abs_RES

Sumber: Pengolahan Data SPSS Tahun 2019

Dari tabel diatas dapat dilihat bahwa:

a. Nilai signifikansi (Sig.) dari variabel Supervisi $\mathrm{X}_{1}$ adalah 0,658 yang berarti $0,658>0,05$, maka tidak terjadi gejala heteroskedastisitas.

b. Nilai signifikansi (Sig.) dari variabel Kemampuan penggunaan Teknologi $X_{2}$ adalah 0,719 yang berarti $0,719>0,05$, maka tidak terjadi gejala heteroskedastisitas.

Dapat disimpulkan bahwa hasil keseluruhan uji prasyarat bahwa layak untuk dilakukan pengujian hipotesis menggunakan uji lainnya demi menjawab hiopotesis yang ada.

\section{Pembahasan Hipotesis Penelitian}

Untuk menunjukkan seberapa jauh pengaruh satu variabel independen (Lingkungan Kerja, Disiplin Kerja dan Motivasi) secara individual dalam menerangkan variabel dependen (kinerja guru). Dasar Pengambilan keputusan pada uji $\mathrm{t}$ dapat dilihat dari kolom signifikansi hasil output SPSS. Apabila nilai sig. $<\alpha$ (0,05), maka $\mathrm{H}_{0}$ ditolak dan $\mathrm{H}_{\mathrm{a}}$ diterima, sehingga variabel independen berpengaruh signifikan terhadap variabel dependen. Sedangkan apabila nilai sig. $>\alpha$ $(0,05)$ maka $\mathrm{H}_{0}$ diterima dan $\mathrm{H}_{\mathrm{a}}$ ditolak, sehingga variabel independen tidak berpengaruh signifikan terhadap variabel dependen.

\section{a. Hipotesis Pertama}

"Terdapat pengaruh positif dan signifikan Supervisi Kepala Madrasah terhadap Kinerja Guru”. Hasil analisis regresi linier:

\begin{tabular}{|c|c|c|c|c|c|}
\hline \multicolumn{6}{|c|}{ Coefficients $^{\mathrm{a}}$} \\
\hline \multirow{2}{*}{ Model } & \multicolumn{2}{|c|}{$\begin{array}{l}\text { Unstandardized } \\
\text { Coefficients }\end{array}$} & \multirow{2}{*}{\begin{tabular}{|c|}
$\begin{array}{c}\text { Standardi } \\
\text { zed } \\
\text { Coefficien } \\
\text { ts }\end{array}$ \\
Beta
\end{tabular}} & \multirow{2}{*}{$\mathrm{t}$} & \multirow{2}{*}{ Sig. } \\
\hline & B & $\begin{array}{l}\text { Std. } \\
\text { Error }\end{array}$ & & & \\
\hline $\begin{array}{l}\text { (Constan } \\
\text { t) }\end{array}$ & 59,579 & 13,735 & & $\begin{array}{r}4,33 \\
8\end{array}$ & ,000 \\
\hline $\begin{array}{l}\text { Supervis } \\
\mathrm{i}\end{array}$ & ,195 &, 059 &, 250 & $\begin{array}{r}3,31 \\
8\end{array}$ & 001 \\
\hline
\end{tabular}

a. Dependent Variable: Kinerja

Berdasarkan tabel tersebut diperoleh persamaan regresi antara variabel Supervisi Kepala Madrasah (X1) terhadap Kinerja Guru (Y) adalah $\hat{\mathrm{Y}}=59,579+$ 0,195X1.

Persamaan regresi tersebut memberikan informasi bahwa setiap perubahan nilai Supervisi Kepala Madrasah sebesar satu satuan, maka akan mempengaruhi kinerja guru sebesar 0,195. Koefisien korelasi bernilai positif artinya terjadi hubungan positif antara Supervisi Kepala Madrasah (X1) terhadap Kinerja Guru (Y).

\begin{tabular}{|c|c|r|r|c|}
\hline $\begin{array}{c}\text { Mode } \\
1\end{array}$ & $\mathrm{R}$ & $\begin{array}{c}\mathrm{R} \\
\text { Square }\end{array}$ & $\begin{array}{c}\text { Adjusted R } \\
\text { Square }\end{array}$ & $\begin{array}{c}\text { Std. Error } \\
\text { of the } \\
\text { Estimate }\end{array}$ \\
\hline 1 &, $247^{\mathrm{a}}$ &, 061 &, 054 & 12,204 \\
\hline
\end{tabular}

a. Predictors: (Constant), Supervisi

Berdasarkan tabel tersebut, maka besarnya pengaruh supervisi kepala madrasah terhadap Kinerja Guru sebesar $6,10 \%$.

\section{b. Hipotesis Kedua}

Hipotesis yang kedua menyatakan "Terdapat pengaruh positif dan signifikan Kemampuan 
Penggunaan Teknologi terhadap Kinerja Guru”. Hasil analisis regresi linier:

\section{Coefficients $^{\mathrm{a}}$}

\begin{tabular}{|l|r|r|r|r|r|}
\hline Model & \multicolumn{2}{|c|}{$\begin{array}{c}\text { Unstandardized } \\
\text { Coefficients }\end{array}$} & $\begin{array}{c}\text { Standardi } \\
\text { zed } \\
\text { Coefficien } \\
\text { ts }\end{array}$ & $\mathrm{t}$ & Sig. \\
\cline { 2 - 4 } & $\mathrm{B}$ & $\begin{array}{c}\text { Std. } \\
\text { Error }\end{array}$ & Beta & & \\
\hline $\begin{array}{l}\text { (Consta } \\
\text { nt) } \\
\begin{array}{l}\text { Teknolo } \\
\text { gi }\end{array}\end{array}$ & 59,579 & 13,735 & & $\begin{array}{r}4,33 \\
8\end{array}$ &, 000 \\
\hline
\end{tabular}

a. Dependent Variable: Kinerja

Sumber: Pengolahan Data SPSS Tahun 2019

Berdasarkan tabel tersebut diperoleh persamaan regresi antara variabel Kemampuan Penggunaan Teknologi (X2) terhadap Kinerja Guru (Y) adalah $\hat{Y}=59,579+0,440$ X2.

Persamaan regresi tersebut memberikan informasi bahwa setiap perubahan nilai Kemampuan Penggunaan Teknologi sebesar satu satuan, maka akan mempengaruhi kinerja guru sebesar 0,440. Koefisien korelasi bernilai positif artinya terjadi hubungan positif antara Kemampuan Penggunaan Teknologi (X2) terhadap Kinerja Guru (Y).

\section{Model Summary ${ }^{\mathrm{b}}$}

\begin{tabular}{|l|l|r|r|r|}
\hline Model & $\mathrm{R}$ & $\begin{array}{r}\mathrm{R} \\
\text { Square }\end{array}$ & $\begin{array}{r}\text { Adjusted } \\
\text { R Square }\end{array}$ & $\begin{array}{r}\text { Std. Error of } \\
\text { the Estimate }\end{array}$ \\
\hline &, $390^{\mathrm{a}}$ &, 103 &, 141 & 11,618 \\
\hline
\end{tabular}

a. Predictors: (Constant), Teknologi, Supervisi

b. Dependent Variable: Kinerja

Berdasarkan tabel tersebut, maka besarnya pengaruh Kemampuan Penggunaan Teknologi terhadap Kinerja Guru sebesar 10,3\%.

\section{c. Hipotesis ketiga}

"Terdapat pengaruh positif dan signifikan Supervisi Kepala Madrasah dan Kemampuan Penggunaan Teknologi terhadap Kinerja Guru”. Hasil analisis regresi linier:

\section{Hasil Uji F}

ANOVA ${ }^{\mathrm{a}}$

\begin{tabular}{|l|r|r|c|c|c|}
\hline Model & $\begin{array}{c}\text { Sum of } \\
\text { Squares }\end{array}$ & df & $\begin{array}{c}\text { Mean } \\
\text { Square }\end{array}$ & $\mathrm{F}$ & Sig. \\
\hline Regressio & 3875,719 & 2 & 1937,85 & 14,538 &, $000^{\mathrm{b}}$ \\
$\mathrm{n}$ & 19594,65 & 14 & 133,297 & & \\
1 Residual & 5 & 7 & & & \\
& & & & \\
Total & 23470,37 & 14 & & & \\
\hline
\end{tabular}

a. Dependent Variable: Kinerja

b. Predictors: (Constant), Teknologi, Supervisi

Sumber: Pengolahan Data SPSS Tahun 2019
Berdasarkan tabel diatas diketahui bahwa nilai signifikansi dalam uji $\mathrm{F}$ sebesar $0,000<$ probabilitas 0,05. Dapat disimpulkan bahwa variabel Supervisi Kepala Madrasah dan variabel Kemampuan Penggunaan Teknologi secara simultan (bersama-sama) memiliki pengaruh terhadap variabel Kinerja.

Berdasarkan tabel diatas diketahui bahwa nilai signifikansi dalam uji $\mathrm{F}$ sebesar $0,000<$ probabilitas 0,05. Dapat disimpulkan bahwa variabel Supervisi Kepala Madrasah dan variabel Kemampuan Penggunaan Teknologi secara simultan (bersama-sama) memiliki pengaruh terhadap variabel Kinerja.

Memperhatikan hasil analisis regresi ganda, menunjukkan persamaan regresi (unstandardized

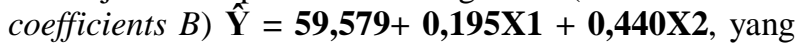
berarti bahwa setiap peningkatan satu unit skor supervisi kepala madrasah dan kemampuan penggunaan teknologi guru secara bersama-sama akan mempengaruhi peningkatan skor kinerja guru sebesar 0,635. Dengan demikian, maka dari kedua variabel di atas ternyata yang paling besar pengaruhnya terhadap kinerja guru adalah variabel kemampuan penggunaan teknologi oleh guru.

Hasil Koefisien Determinan (KD) Model Summary

\begin{tabular}{|l|c|r|r|c|}
\hline $\begin{array}{l}\text { Mode } \\
1\end{array}$ & $\mathrm{R}$ & $\begin{array}{c}\mathrm{R} \\
\text { Square }\end{array}$ & $\begin{array}{c}\text { Adjusted } \\
\text { R Square }\end{array}$ & $\begin{array}{c}\text { Std. Error } \\
\text { of the } \\
\text { Estimate }\end{array}$ \\
\hline 1 &, $406^{\mathrm{a}}$ &, 165 &, 154 & 11,545 \\
\hline
\end{tabular}

a. Predictors: (Constant), Teknologi, Supervisi

Dari tabel tersebut dapat diketahui bahwa nilai koefisien determinasi (kontribusi) pengaruh variabel Supervisi dan variabel Kemampuan Penggunaan Teknologi secara simultan (bersama-sama) terhadap variabel kinerja ( $\mathrm{R}$ square) adalah sebesar 0,165. Artinya variabel supervisi dan variabel Kemampuan Penggunaan Teknologi secara bersama-sama memiliki pengaruh terhadap variabel Kinerja sebesar $16,5 \%$ dan $83,5 \%$ dipengaruhi oleh faktor lainnya.

\section{KESIMPULAN DAN SARAN \\ Kesimpulan}

1. Terdapat pengaruh positif dan signifikan antara supervisi kepala madrasah terhadap kinerja guru. Adapun besarnya pengaruh ditunjukkan oleh koefisien determinasi $\mathrm{R}^{2}(R$ square $)=$ 0,061 , yang berarti bahwa supervisi kepala madrasah memberikan pengaruh terhadap kinerja guru sebesar $6,1 \%$ dan sisanya yaitu 93,9\% ditentukan oleh faktor lainnya. Hasil analisis regresi sederhana, menunjukkan persamaan regresi $\hat{Y}=59,579+0,195 X 1$, yang berarti setiap peningkatan satu nilai supervisi kepala madrasah akan diikuti peningkatan nilai kinerja guru sebesar 0,195.

2. Terdapat pengaruh positif dan signifikan antara kemampuan penggunaan teknologi terhadap kinerja guru. Adapun besarnya pengaruh 
ditunjukkan oleh koefisien determinasi $\mathrm{R}^{2}(R$ square) $=0,103$, yang berarti bahwa kemampuan penggunaan teknologi memberikan pengaruh terhadap kinerja guru sebesar $10,3 \%$ dan sisanya yaitu 89,7\% ditentukan oleh faktor lainnya. Hasil analisis regresi sederhana menunjukkan persamaan regresi $\hat{Y}=59,579+0,440 X 2$ yang berarti bahwa setiap peningkatan satu nilai kemampuan penggunaan teknologi guru akan diikuti peningkatan nilai kinerja guru sebesar 0,440 .

3. Terdapat pengaruh positif dan signifikan antara supervisi kepala madrasah dan kemampuan penggunaan teknologi secara bersama-sama terhadap kinerja guru. Adapun besarnya pengaruh ditunjukkan oleh koefisien determinasi $\mathrm{R}^{2}(R$ square $)=0,165$, yang berarti bahwa supervisi kepala madrasah dan kemampuan penggunaan teknologi secara bersama-sama memberikan pengaruh terhadap kinerja guru sebesar $16,5 \%$ dan sisanya yaitu $83,5 \%$ ditentukan oleh faktor lainnya. Hasil analisis regresi sederhana menunjukkan persamaan $\hat{\mathrm{Y}}=59,579+0,195 \mathrm{X} 1+0,440 \mathrm{X} 2$.

Saran

1. Dengan besarnya pengaruh kemampuan penggunaan teknologi terhadap kinerja guru, maka disarankan kepada guru untuk selalu meningkatkan dan memperbaiki kemampuan penggunaan teknologi guru sebagai acuan dan dasar yang harus dimiliki oleh seorang guru, dalam upaya pencapaian tujuan pembelajaran yang baik dan tentunya dalam upaya peningkatan kinerja guru.

2. Kepala madrasah selaku pimpinan di madrasah agar dapat terus meningkatkan supervisi kepala madrasah, melalui supervisi yang dilakukan kepala madrasah maka guru akan senantiasa mendapat pembinaan, perhatian serta pegawasan yang baik dari kepala madrasah , melalui perencanaan supervisi kepala madrasah , pelaksanaan supervisi kepala madrasah serta tindak lanjut yang dilakukan kepala madrasah , sehingga diharapkan guru akan dapat meningkatkan kinerjanya dan lebih jauh lagi dalam upaya pencapaian tujuan pembelajaran yang diharapkan.

3. Guru sebagai pihak yang berperan penting dalam suksesnya pembelajaran agar tetap melakukan peningkatan kemampuan penggunaan teknologi mengikuti perkembangan zaman dan pembaharuan proses pembelajaran sebagai implikasi dari profesionalitas guru.

4. Penelitian dalam bidang pendidikan khususnya pada ranah supervisi kepala madrasah dan kemampuan penggunaan teknologi guru serta kinerja guru agar dapat dipertajam dan didukung dari berbagai pihak dan sumber sehingga hasil penelitian akan memberikan acuan yang baik guna meningkatkan mutu pendidikan, khususnya di Kota Medan dan umumnya di Indonesia.

\section{DAFTAR PUSTAKA}

[1] Anwar Prabu Mangkunegara, 2000, Manajemen Sumber Daya Manusia Perusahaan, Bandung: Remaja Rosdakarya

[2] Arikunto, Suharsimi, 2000, Metodologi Penelitian, Jakarta: Rineka Cipta

[3] Darmawan Deni, 2012, Teknologi Pembelajaran, Bandung: Remaja Rosdakarya,

[4] Darmawan Deni, 2014, Inovasi Pendidikan; Pendekatan Praktik Teknologi Multimedia

[5] Direktorat Tenaga Kependidikan, 2010, Supervisi Akademik : Materi Pelatihan Penguatan Kemampuan Kepala Sekolah.

[6] Emzir, 2013, Metode Penelitian Pendidikan, Jakarta : Rajawali Pers

[7] Fattah. 2008, Landasan Manajemen Pendidikan . PT. Remaja Yokyakarta. Bandung

[8] Husain Chaidar, 2014, "Pemanfaatan Teknologi Informasi dan Komunikasi dalam Pembelajaran di SMA Muhammadiyah Tarakan", Jurnal Kebijakan dan Pengembangan Pendidikan, Volume 2, Nomor 2 (Juli 2014), 189.

[9] Juni Priansa, Doni, dan Somad Rismi. 2014. Manajemen Supervisi dan Kepemimpinan Kepala Sekolah, Alfabeta: Bandung

[10] Mulyasa. 2012. Menjadi Kepala Sekolah Profesional. Bandung: Remaja Rosdakarya.

[11] Peraturan Menteri Pendidikan Nasional Republik Indonesia Nomor 13 tahun 2007 tentang standar kepala sekolah.

[12] Peraturan Menteri Pendidikan Nasional Republik Indonesia Nomor 28 Tahun 2010 tentang Penugasan Guru Sebagai Kepala Sekolah/Madrasah

[13] Peraturan Menteri Pendidikan Nasional Republik Indonesia Nomor 16 Tahun 2007 Tentang Standar Kualifikasi Akademik dan Kompetensi Guru.

[14] Peraturan Menteri Pendidikan Nasional Republik Indonesia Nomor 20 Tahun 2003, Tentang Standar Kepala Sekolah.

[15] Peraturan Menteri Pendidikan Nasional Republik Indonesia Nomor 41 Tahun 2007 Tentang Standar Proses untuk Satuan Pendidikan Dasar dan Menengah.

[16] Pidarta Made, 2009, Supervisi Pendidikan Kontekstual, Cet. I, Jakarta: Rineka Cipta.

[17] Sahertian, 2000, Konsep Dasar dan Teknik Supervisi Pendidikan dalam Rangka Pengembangan Sumber Daya Manusia, Jakarta: Rineka Cipta

[18] Sugiyono, 2008, Metode Penelitian Pendidikan Pendekatan Kuantitatif, Kualitatif, dan $R \& D$, Bandung, Alfabeta 
[19] Sukardi, 2013, Metodologi Penelitian Pendidikan, Jakarta: BumiAksara

[20] Supardi. 2013. Kinerja Guru. Jakarta: PT Raja Grafindo Persada.

[21] Undang-Undang RI No.14 Tahun 2005 tentang Guru dan Dosen. 